\title{
KAJI TERAP TEKNOLOGI KOMPOSTING UNTUK PENANGANAN LIMBAH TERNAK SAPI POTONG
}

\section{Assess the Applicability of Composting Technology for Beef Cattle Waste Handling}

\author{
FIRMAN L. SAHWAN \\ Peneliti Pusat Teknologi Lingkungan, Badan Pengkajian dan Penerapan Teknologi \\ Gedung 820 Geostech, Kawasan Puspiptek Serpong, Tangerang Selatan, Provinsi Banten, 15314 INDONESIA \\ firmanlailisahwan@gmail.com
}

\begin{abstract}
Waste from beef cattle house including cow dung, can be utilized as main raw material in the production of organic fertilizer (compost). However, organic fertilizer made from beef cattle waste has some problems. This study was done to characterize organic fertilizer made from beef cattle waste and evaluate its positive and negative factors, as well as suggestion in order to improve the quality of the product of organic fertilizer. The study concluded that the main macro-nutrients content, Fe content, $\mathrm{pH}$ and the presence of functional microbial meet the requirements stated in the Minister of Agriculture Regulation (Permentan) No. 70 Year 2011. It indicates that organic fertilizer made from manure and other wastes associated with cultured beef cattles shows a good quality product. However on the other hand, microbial contaminants (E. coli and Salmonella $s p)$, that were positively found in fresh manure even negatively found in dry manure indicated a less quality of the produced organic fertilizer. Also, the characterization of the maturity level of produced organic fertilizer is not considered as stable or mature fertilizer. Both problems are often encountered in the production of organic fertilizer using beef cattle waste as raw material. The suggestion solution is to employ the composting technology to extend the time of decomposition process until it is obtained the product of fertilizer that meets the criteria of mature organic fertilizer (compost). The decomposition process is under aerobic condition that generates high temperatures for killing pathogens (contaminants) and weed seeds.
\end{abstract}

Keywords: Composting technology, solid waste, beef cattle, organic fertilizer, compost.

\begin{abstract}
ABSTRAK
Limbah kandang sapi potong dan kotoran sapinya adalah bahan baku utama pupuk organik (kompos). Namun, pembuatan pupuk organik berbahan baku limbah kandang masih memiliki masalah. Penelitian ini bertujuan untuk mengetahui karakteristik pupuk organik berbahan baku limbah kandang dan mengevaluasi faktor positif dan negatifnya, serta memberikan masukan untuk meningkatkan kualitas pupuk. Hasil penelitian menunjukkan bahwa kandungan unsur hara makro utama, kadar $\mathrm{Fe}, \mathrm{pH}$ dan keberadaan mikroba fungsional telah memenuhi persyaratan yang ditetapkan dalam Permentan No. 70 Tahun 2011. Adanya parameter-parameter tersebut menunjukkan bahwa pupuk organik yang dibuat dari limbah kandang memiliki kualitas yang baik. Keberadaan mikroba kontaminan (E. coli dan Salmonella $\mathrm{sp}$ ) yang positif pada pukan segar walaupun negatif pada pukan kering mengindikasikan kualitas produk pupuk organik yang kurang baik. Selain itu, analisa produk pupuk belum menunjukkan adanya kestabilan atau kematangan yang cukup. Kedua hal tersebut merupakan permasalahan yang sering dihadapi pada pembuatan pupuk organik berbahan baku limbah kandang termasuk kotoran sapi. Solusinya adalah memperpanjang waktu proses dekomposisi sampai diperoleh kematangan yang tepat, dengan penggunaan teknologi komposting. Proses dekomposisinya akan berjalan secara aerobik sehingga menghasilkan suhu tinggi yang dapat membunuh mikroba patogen (kontaminan) dan bibit gulma.
\end{abstract}

Kata kunci: Teknologi komposting, limbah padat, sapi potong, pupuk organik, kompos.

\section{PENDAHULUAN}

Program swasembada daging sapi yang ditargetkan tahun 2014, telah memacu berkembangnya usaha peternakan sapi potong lokal. Hal ini terkait dengan sasaran program tersebut yaitu meningkatnya populasi sapi potong 
menjadi 14,2 juta ekor pada tahun 2014 dengan rata-rata pertumbuhan sebesar $12,48 \%$. Atau meningkatnya produksi daging sapi dalam negri sebesar 420,3 ribu ton pada tahun 2014, yang setara dengan peningkatan $10,4 \%$ setiap tahunnya ${ }^{(1)}$.

Pada sisi lain, untuk memenuhi kebutuhan daging sapi perkapita sebanyak 2,2 kg, Menteri Perdagangan menyatakan bahwa Indonesia membutuhkan impor sapi sebanyak 750 ribu pertahun ${ }^{(2)}$. Konsekuensi logis dari kebijakan tersebut, adalah berkembangnya usaha peternakan penggemukan sapi impor.

Implikasinya adalah meningkatnya populasi sapi lokal maupun impor, meningkatnya produksi daging, serta banyaknya hasil ikutannya berupa produksi kotoran hewan (kohe). Pada sebagian peternak kohe ini dianggap sebagai hal yang positif, karena dapat dimanfaatkan sebagai pupuk organik, sehingga dapat menjadi sumber tambahan pendapatan peternak. Namun, pada peternak lain yang tidak memanfaatkan kohenya, keberadaan kohe ini cukup membebani. Secara periodik peternak harus membersihkan kandang dari kohe, yang sudah tentu membutuhkan biaya dan tenaga.

Tingginya potensi limbah kohe, karena ratarata produksi kotoran sapi potong di Indonesia sebesar $25 \mathrm{~kg}$ per ekor per hari. Dengan populasi ternak sapi potong tahun 2013 sebanyak 16.607.000 ekor ${ }^{(3)}$, maka akan dihasilkan 415.175 ton kohe segar per hari. Pemanfaatan kohe sebagai pupuk organik, merupakan salah satu jalan keluar mengatasi permasalahan limbah kohe. Hal ini juga sejalan dengan salah satu program aksi dari program swasembada daging sapi, yaitu pengembangan usaha pupuk organik dan sistem jaringan pemasarannya ${ }^{(2)}$.

Yang dimaksud dengan pupuk organik adalah pupuk yang berasal dari tumbuhan mati, kotoran hewan dan/atau bagian hewan dan/atau limbah organik lainnya yang telah melalui proses rekayasa, berbentuk padat atau cair, dapat diperkaya dengan bahan mineral dan/atau mikroba, yang bermanfaat untuk meningkatkan kandungan hara dan bahan organik tanah, serta memperbaiki sifat fisik, kimia dan biologi tanah ${ }^{(4)}$.

Berbagai istilah atau nama pupuk organik sudah dikenal. Namun umumnya dikelompokkan menjadi 3 (tiga) jenis, yaitu: pupuk kandang, pupuk hijau dan kompos. Pupuk kandang (pukan) merupakan limbah kandang, yang merupakan campuran alas kandang (serbuk gergaji/jerami/sekam) dengan kotoran hewan, yang biasanya didiamkan terlebih dahulu dengan cara ditumpuk selama 1,5-2 bulan, sebelum digunakan. Pupuk hijau merupakan pupuk organik yang berasal dari daun-daunan, terutama daun kacang-kacangan (leguminosa), yang dibenamkan ke dalam tanah. Sedangkan kompos merupakan pupuk organik berupa materi yang sederhana dan relatif stabil yang dihasilkan dari suatu proses dekomposisi (penguraian) berbagai materi organik yang kompleks secara biologis oleh konsorsium mikroorganisme dalam kondisi aerobik dan termofilik yang terkendali ${ }^{(5,6,7)}$.

Pupuk organik sangat dibutuhkan, karena dapat memperbaiki sifat fisik, kimia dan biologi tanah secara sekaligus. Dalam beberapa tahun terakhir ini pupuk organik banyak diproduksi sebagai salah satu upaya Pemerintah untuk memperbaiki kualitas lahan pertanian, khususnya untuk meningkatkan kandungan C-organik tanah yang $73 \%$ tergolong rendah $(<2 \%), 23 \%$ tergolong sedang (2-3\%) dan hanya $4 \%$ yang tergolong tinggi $(>3 \%)^{(8)}$, atau $65 \%$ dari 7,9 juta hektar lahan sawah di Indonesia memiliki kandungan bahan organik rendah sampai sangat rendah $(\mathrm{C} \text {-organik }<2 \%)^{(9)}$. Kandungan $\mathrm{C}$-organik tanah umumnya tidak banyak $(2-10 \%)$, namun perannya sangat penting terhadap kesuburan tanah dan nutrisi tanaman ${ }^{(10)}$ sehingga disebut sebagai nyawanya tanah ${ }^{(11)}$.

Kohe khususnya yang berasal dari sapi merupakan bahan baku utama pupuk organik yang sangat dominan dan diminati ${ }^{122}$. Dengan memanfaatkan kohe sebagai pupuk organik, maka dua manfaat dapat diperoleh sekaligus yaitu mengatasi permasalahan limbah kohe dan menghasilkan pupuk organik untuk memperbaiki kualitas lahan pertanian.

Namun penggunaan kohe sapi sebagai bahan baku pupuk organik, bukan tanpa masalah ${ }^{(13)}$. Kandungan Fe pada kohe sapi dilaporkan tinggi. Angka kandungan $\mathrm{Fe}$ pada kohe sapi berkisar antara $12.600-59.000 \mathrm{ppm}$, dengan rata-rata $21.782 \mathrm{ppm}^{(14)}$. Padahal kandungan Fe maksimal yang diperkenankan adalah $9.000 \mathrm{ppm}^{(3)}$.

Salah satu peternakan sapi potong yang kebetulan diteliti adalah milik PT Gunung Permata Jaya yang terletak di Kecamatan Cijapati, Kabupaten Bandung. Peternakan tersebut merupakan tempat penggemukan sapi potong impor yang berasal dari Australia. Di dalamnya terdapat kandang-kandang model koloni yang dapat menampung minimal 2.000 ekor sapi. Setiap harinya rata-rata sapi yang menghuni peternakan tersebut sebanyak 1.000 ekor sapi. Sapi impor yang dipelihara terbagi dalam dua jenis, yaitu feeder dan slaughter. Jenis feeder merupakan sapi yang masih dalam pertumbuhan yang kemudian digemukkan dalam waktu minimal 2 (dua) bulan. Pada saat datang, rata-rata bobot badan sapi feeder jantan (Bulls) adalah310 kg. Sedangkan yang jenis slaughter merupakan sapi yang sudah besar dan siap 
potong. Bobot badannya minimal sudah mencapai $360 \mathrm{~kg}$ dan biasanya dipelihara minimal 1 (satu) minggu dalam rangka pemulihan kondisi fisiknya.

Limbah kandang dari peternakan tersebut yang berupa campuran dari kohe dan alas kandang, secara periodik dikumpulkan. Dengan menggunakan teknologi yang sederhana, pukan tersebut diproses menjadi pupuk organik dalam bentuk pupuk organik remah dan pupuk organik granul (POG). Pembuatannya mengandalkan pada proses pengeringan menggunakan sinar matahari, dengan cara dihamparkan dan dibolak balik di tempat terbuka. Dengan cara seperti itu, sulit mendapatkan temperatur yang cukup untuk dapat membunuh bakteri patogen, atau mikroba kontaminan. Yang dimaksud dengan mikroba kontaminan adalah $E$. coli dan Salmonella $s p .^{(3,15)}$. Kedua jenis mikroba tersebut termasuk jenis mikroba yang patogen, dan keberadaannya dijadikan sebagai parameter adanya bakteri patogen yang lain. Bakteri E.coli dan Salmonella $s p$., banyak hidup di dalam saluran pencernaan hewan, dan bersifat patogen bila berada di luar usus. Oleh karena itu, pupuk organik yang diproduksi, cukup rentan untuk terpapar dengan bakteri patogen.

Permasalahan selanjutnya adalah proses dekomposisi yang kurang sempurna, akan mempengaruhi tingkat kematangan pupuk organik. Permasalahan-permasalahan tersebut di atas, dicoba untuk dianalisis dan dievaluasi untuk dicarikan opsi optimasinya dalam rangka mendapatkan pupuk organik yang berkualitas. Untuk itulah penelitian ini dilakukan.

Dengan demikian, tujuan penelitian ini adalah: mengevaluasi proses pembuatan pupuk organik; menganalisis kandungan $\mathrm{Fe}$; mengetahui keberadaan mikroba kontaminan, menilai tingkat kematangan pupuk organik; serta memberikan saran perbaikan terhadap proses produksi yang biasa dilaksanakan.

\section{BAHAN DAN METODE}

\subsection{Tempat dan Waktu Penelitian}

Penelitian dilakukan di Peternakan Penggemukan Sapi Potong milik PT Gunung Permata Jaya, yang terletak di Kecamatan Cijapati, Kabupaten Bandung. Sedangkan rentang waktu penelitiannya dilakukan mulai bulan Juli sampai dengan bulan Nopember 2014.

\subsection{Cara Penelitian}

Observasi lapangan dan wawancara, dilakukan dalam rangka untuk mengetahui kondisi peternakan, tata kelola pemeliharaan ternak, potensi timbulan limbah padat, dan tatacara proses pembuatan pupuk organik yang biasa dilakukan. Wawancara dilakukan terhadap pengelola peternakan, karyawan kandang dan karyawan yang membuat pupuk.

Pengambilan sampel pupuk organik, yang dikelompokkan kedalam 3 (tiga) kategori yaitu:

a. Limbah padat segar yang berasal dari pembersihan kandang.

b. Pupuk kandang (pukan) kering yaitu pukan yang sudah melalui proses pengeringan.

c. Pupuk organik berupa pupuk yang sudah selesai diproses dan siap dipasarkan.

Tujuan pengelompokan tersebut adalah untuk mengetahui apakah ada perbedaan karakter pupuk organik pada setiap kategori tersebut.

Analisa laboratorium, dilakukan di Laboratorium Tanah, Balai Penelitian Tanah Bogor. Parameter analisisnya adalah: kandungan $\mathrm{Fe}$, keberadaan bakteri patogen dan fungsional, tingkat kematangan (rasio $\mathrm{C} / \mathrm{N}, \mathrm{pH}$, rasio $\mathrm{N}-\mathrm{NO}_{3} / \mathrm{N}-\mathrm{NH}_{4}$, perbandingan $\mathrm{N}-\mathrm{NH}_{4}$ terhadap $\mathrm{N}$ total dan $\mathrm{KTK}$ ), serta kandungan unsur hara makro utama ( $N$ total, $\mathrm{P}_{2} \mathrm{O}_{5}$ dan $\mathrm{K}_{2} \mathrm{O}$ ).

Analisa proses pembuatan pupuk organik dan optimasinya melalui teknologi komposting, bertujuan untuk menganalisis proses pembuatan pupuk organik, terutama yang berkaitan dengan hal-hal yang belum optimal, untuk kemudian diberikan opsi optimasinya, berupa teknologi komposting. Teknologi komposting yang diusulkan harus bersifat mudah dilakukan, tidak terlalu merubah tatacara proses dan tidak banyak menambah biaya produksi.

\section{HASIL DAN PEMBAHASAN}

\subsection{Pola Pemeliharaan Ternak Sapi dan Timbulan Limbah Padat}

Ternak sapi dipelihara di dalam kandang sistem koloni. Artinya dalam satu blok kandang diisi oleh banyak sapi sesuai dengan kapasitas kandang. Kandang diberi alas serbuk gergaji dengan rata-rata ketebalan $3-4 \mathrm{~cm}$ dari permukaan lantai.

Air minum diberikan secara tidak terbatas. Sedangkan pakan sapi diberikan secara bergantian antara hijauan (sumber serat) dengan konsentrat sesuai kebutuhan yang sudah ditentukan. Jenis hijauan yang diberikan biasanya berupa: jerami padi, batang dan daun jagung, serta rumput gajah (Pinnesetum purpureum).

Ternak sapi akan menghasilkan kohe dan urine yang kemudian bercampur dengan alas kandang. Selama di dalam kandang koloni tersebut, ternak sapi tidak dimandikan atau tidak dibersihkan. Semakin lama kohe dan urine 
tersebut semakin banyak sehingga alas kandang yang bercampur dengan kohe dan urine menjadi semakin banyak dan semakin basah. Setelah 1 (satu) minggu atau ketinggian campuran kohe, urine dan serbuk gergaji mencapai $30 \mathrm{~cm}$ dari lantai, kandang dibersihkan. Campuran kohe, urine dan serbuk gergaji dikeluarkan dari kandang dan biasanya disebut dengan limbah atau pupuk kandang. Kemudian alas kandang diberi serbuk gergaji yang baru lagi. Demikian seterusnya.

\subsection{Proses Pembuatan Pupuk Organik}

Campuran serbuk gergaji, kohe dan urine yang dikeluarkan dari kandang (limbah kandang) merupakan bahan baku utama pembuatan pupuk organik. Dari segi rasio $\mathrm{C} / \mathrm{N}$, campuran kohe dan serbuk gergaji cukup positif. Kohe yang jumlahnya jauh lebih banyak, memiliki rasio $\mathrm{C} / \mathrm{N}$ yang rendah, yakni $20-25^{(16)}$. Sedangkan serbuk gergaji yang jumlahnya sedikit, rasio $\mathrm{C} / \mathrm{N}$ nya tinggi, yakni $511^{(6)}$. Kalau campuran keduanya bisa menghasilkan rasio $\mathrm{C} / \mathrm{N}$ sekitar 30, merupakan angka yang ideal sekali, karena proses dekomposisi untuk menghasilkan pupuk organik yang siap pakai bisa berjalan cepat. Namun sebaliknya, kalau campuran keduanya menghasilkan perbandingan $\mathrm{C} / \mathrm{N}$ yang tinggi $(>40)$, proses dekomposisi akan berjalan lambat, sehingga pupuk organik yang dihasilkan cenderung untuk tidak matang atau tidak siap pakai. Kalau $\mathrm{C} / \mathrm{N}$ nya terlalu rendah maka akan banyak unsure $\mathrm{N}$ yang hilang dalam bentuk amoniak $^{(6,7)}$.

Campuran serbuk gergaji, kohe dan urine biasanya ditumpuk di lahan kosong selama kurang lebih 3 minggu untuk menurunkan kadar airnya. Setelah agak kering, limbah padat tersebut dihamparkan pada tempat-tempat terbuka yang kosong, dengan tujuan untuk pengeringan. Untuk mempercepat proses pengeringan, maka hamparan campuran kohe, dibuat tidak terlalu tebal $(30-40 \mathrm{~cm})$ dan setiap hari dilakukan pembolakbalikan pakai garu. Proses ini biasanya dilakukan selama 1 (satu) minggu. Hal yang tidak menguntungkan dari proses ini adalah: memerlukan lahan yang luas; mudah terkontaminasi dengan bibit gulma di sekitarnya; ketebalan hamparan kohe tidak cukup untuk menghasilkan proses pemanasan sendiri, sehingga kemungkinan tidak dapat untuk membunuh bakteri patogen dan bibit gulma; proses dekomposisi berjalan lambat; tercucinya unsur hara pada saat hujan; serta membutuhkan tenaga kerja yang banyak.

Setelah limbah kandang dianggap cukup kering (pupuk kandang), proses selanjutnya adalah penghancuran atau penghalusan materi menggunakan shredder, dan dilanjutkan dengan proses penyaringan agar diperoleh pupuk organik halus. Pupuk organik halus tersebut kemudian dimasukkan dalam karung (dikemas).

Sebagian dari pupuk organik halus yang dihasilkan ada pula yang dilanjutkan dengan proses granulasi menggunakan pan granulator sehingga dihasilkan pula pupuk organik granul (POG).

\subsection{Kandungan Fe}

Kandungan $\mathrm{Fe}$ untuk limbah padat segar, pupuk kandang (pukan) kering dan pupuk organik berturut-turut sebesar 1.153 ppm, 6.650 ppm dan 4.673 ppm. Hasil analisa laboratorium tersebut berada di bawah baku mutu yang ditetapkan oleh Permentan 70 Tahun $2011^{(3)}$ yaitu sebesar 9.000 ppm. Dengan demikian pukan ataupun pupuk organik berbahan baku pukan, aman dari permasalahan tingginya kandungan Fe.

Sering dikemukakan bahwa kotoran hewan (kohe) sapi atau pupuk organik berbahan baku utama kohe sapi memiliki kandungan $\mathrm{Fe}$ yang tinggi melebihi Permentan 70 tahun $2011^{(14)}$.

\subsection{Keberadaan Mikroba Kontaminan}

Dalam penelitian ini, yang dimaksud dengan mikroba kontaminan adalah $E$. coli dan Salmonella $s p .^{(3,15)}$. Kedua jenis mikroba tersebut termasuk jenis mikroba yang patogen, dan keberadaannya dijadikan sebagai parameter adanya bakteri patogen yang lain.

Hasil analisa laboratorium menunjukkan bahwa limbah padat segar mengandung mikroba kontaminan, baik E. coli maupun Salmonella sp. Kandungan $E$. coli sebesar 1,63 x $10^{3} \mathrm{MPN} / \mathrm{g}$ dan Salmonella $s p$. sebesar $3,6 \times 10^{3} \mathrm{MPN} / \mathrm{g}$. Sedangkan pada pukan kering dan pada pupuk organik tidak ditemukan adanya ke dua jenis mikroba kontaminan tersebut. Kemungkinan penyebabnya adalah bakteri kontaminan tersebut telah mati oleh proses pengeringan. Namun, proses pengeringan yang ada tidak menjamin akan selalu dapat membunuh mikroba kontaminan karena suhu yang terbentuk tidak terlalu tinggi. Dengan demikian, peluang keberadaan mikroba kontaminan pada pukan kering dan pupuk organik pada waktu yang lain masih tetap ada.

Agar keberadaan mikroba kontaminan dan bibit gulma bisa dihilangkan, maka perlu adanya modifikasi proses. Proses yang diperlukan adalah yang dapat menghasilkan suhu tinggi dari proses itu sendiri (self heating). Self heating akan terjadi apabila pukan segar ditumpuk dengan ukuran minimal $1 \times 1 \times 1 \mathrm{~m}^{3}$ dan secara periodik (misalnya setiap minggu) dilakukan 
pengadukan/pembalikan tumpukan minimal 1 kali seminggu $^{(7)}$.

\subsection{Analisis Tingkat Kematangan}

Tingkat kematangan pupuk organik yang dibuat dari pukan di peternakan sapi potong Cijapati, disajikan pada Tabel 1 .

Berdasarkan rasio $\mathrm{C} / \mathrm{N}$ maka baik limbah padat segar, pukan kering maupun pupuk organik telah menunjukkan ciri pupuk organik (kompos) matang. Namun bahan baku utama pupuk yang diteliti adalah kotoran hewan, maka ada keraguan terhadap rasio $\mathrm{C} / \mathrm{N}$ yang sudah < 20 apakah karena proses dekomposisi yang sudah matang atau karena bahan bakunya memang memiliki rasio $\mathrm{C} / \mathrm{N}$ yang $<20$. Hal ini terutama apabila keseluruhan bahan baku yang digunakan berupa kotoran hewan.

Tabel 1. Tingkat Kematangan Pupuk Organik Berbahan Baku Limbah Kandang.

\begin{tabular}{llllll}
\hline No & Parameter & Standar & $\begin{array}{l}\text { Limbah Padat } \\
\text { segar }\end{array}$ & Pukan Kering & Pupuk Organik \\
\hline 1 & Rasio C/N & $<20^{(6, /)}$ & 7 & 10 & 13 \\
2 & $\mathrm{pH}$ & $>7,5^{(6)}$ & 8,2 & 7,6 & 8,0 \\
3 & Rasio N-NO $3 / \mathrm{N}^{(6)}$ & $>1^{(1 /)}$ & 0,65 & 0,8 & 0,79 \\
4 & Rasio N-NH $4-\mathrm{N}$-total & $<10 \%{ }^{(16)}$ & $>10 \%$ & $>10 \%$ & $>10 \%$ \\
5 & KTK & $>60 \mathrm{meq} / 100 \mathrm{~g}^{(6)}$ & $11,17 \mathrm{cmol}(+) / \mathrm{kg}$ & $8,22 \mathrm{cmol}(+) / \mathrm{kg}$ & $20,58 \mathrm{cmol}(+) / \mathrm{kg}$
\end{tabular}

Catatan: Analisa dilakukan di Balai Penelitian Tanah, Bogor

Tabel 2. Kandungan Unsur Hara Makro Utama

\begin{tabular}{|c|c|c|c|c|c|c|c|}
\hline \multirow{2}{*}{ NO } & \multirow{2}{*}{ Jenis Pupuk } & \multirow{2}{*}{ Satuan } & \multicolumn{4}{|c|}{ Kandungan Unsur Hara Makro Utama } & \multirow{2}{*}{$\begin{array}{c}\text { Permentan } 70 \text { Th } \\
2011 \\
\text { Total N+P+K }\end{array}$} \\
\hline & & & N-total & $\mathrm{P}_{2} \mathrm{O}_{5}$ & $\mathrm{~K}_{2} \mathrm{O}$ & $\begin{array}{c}\text { Total } \\
\mathrm{N}+\mathrm{P}+\mathrm{K}\end{array}$ & \\
\hline 1 & Limbah Padat Segar & $\%$ & 1,38 & 0,17 & 0,52 & 2,07 & Minimal 4 \\
\hline 2 & Pukan Kering & $\%$ & 0,61 & 0,48 & 1,01 & 2,1 & Minimal 4 \\
\hline 3 & Pupuk Organik & $\%$ & 1,28 & 1,25 & 2,20 & 4,73 & Minimal 4 \\
\hline
\end{tabular}

Catatan : Analisa dilakukan di Laboratorium Balai Penelitian Tanah, Bogor.

Demikian juga nilai $\mathrm{pH}$ yang di atas 7,5 , sudah memenuhi kriteria kompos matang. Nilai $\mathrm{pH}$ yang rendah biasanya hanya terjadi di awal proses dekomposisi. Setelah 2 minggu proses dekomposisi $i^{(6)}$ biasanya nilai $\mathrm{pH}$ sudah bersifat basa. Untuk itu $\mathrm{pH}$ bukan penentu kriteria kematangan pupuk organik yang utama ${ }^{(6)}$. Nilai $\mathrm{pH}$ pukan yang diteliti sudah memenuhi pula persyaratan Permentan 70 tahun $2011^{(3)}$.

Sedangkan parameter kematangan lain seperti rasio $\mathrm{N}-\mathrm{NO}_{3} / \mathrm{N}-\mathrm{NH}_{4}$, rasio $\mathrm{N}-\mathrm{NH}_{4}-\mathrm{N}$-total dan KTK menunjukkan bahwa limbah padat segar, pukan kering maupun pupuk organik, belum memenuhi kriteria pupuk organik yang sudah stabil atau matang.

Agar pupuk organik berbahan baku limbah padat kandang dapat memenuhi kriteria pupuk organik (kompos) matang atau stabil, diperlukan modifikasi proses terutama berupa perpanjangan waktu proses dekomposisi. Hal ini yang dikenal dengan teknologi proses komposting.

\subsection{Kandungan Unsur Hara Makro Utama}

Dalam penelitian ini yang dimaksud dengan unsur hara makro utama adalah $\mathrm{N}, \mathrm{P}$ dan $\mathrm{K}^{(10)}$. Kandungan unsur hara makro utama pupuk organik yang diteliti, disajikan pada Tabel 2 . Hasilnya tidak jauh berbeda dengan pupuk organik sejenis yang dibuat secara modern di Rumah Pemotongan Hewan Cakung, Jakarta Timur $^{(19,20)}$. Secara aturan, pupuk organik yang diteliti memenuhi Permentan 70 Tahun $2011^{(3)}$, yaitu total hara makro utama $>4 \%$. 


\subsection{Kandungan Mikroba Fungsional}

Yang dimaksud dengan mikroba fungsional adalah bakteri penambat $\mathrm{N}$ dan bakteri pelarut $\mathrm{P}^{(3)}$. Secara alamiah ke dua bakteri tersebut, ada di dalam bahan organik yang mengalami proses dekomposisi ${ }^{(6)}$. Bakteri penambat $\mathrm{N}$ pada pupuk organik yang diteliti sebanyak $4,9 \times 10^{6}$, telah memenuhi syarat sebagai pupuk organik menurut Permentan 70 tahun $2011^{(3)}$. Namun untuk bakteri pelarut $\mathrm{P}$ nya tidak terdeteksi. Kemungkinan penyebabnya adalah jumlah mikrobanya terlalu sedikit (banyak yang mati), sehingga tidak terdeteksi. Pada pupuk sejenis, yaitu kompos RPH Cakung bakteri pelarut $\mathrm{P}$, dilaporkan terdeteksi sebanyak $1,6 \times 10^{5}$ (21).

\subsection{Optimasi Proses Dengan Teknologi Komposting}

Berdasarkan hasil dan pembahasan yang telah disampaikan, terlihat adanya dua permasalahan utama pada proses pembuatan pupuk organik di peternakan sapi potong milik PT. Gunung Permata Jaya. Permasalahan pertama adalah tingkat kematangan pupuk organik, dan permasalahan ke dua adalah kemungkinan terkontaminasi dengan mikroba patogen dan bibit gulma.

Proses dekomposisi pukan sebaiknya dapat berjalan dengan baik, dan dengan waktu yang cukup. Proses yang diharapkan terjadi adalah proses pengomposan aerobik, sehingga proses dekomposisinya dapat berjalan lebih cepat dan menghasilkan suhu tinggi yang dapat membunuh mikroba patogen dan bibit gulma $a^{(6,7)}$.

Untuk itu alternatif opsi optimasi yang disarankan adalah sebagai berikut:

a. Proses dekomposisi dilaksanakan di bangunan yang beratap, yang didalamnya terdapat bak berukuran panjang dan lebar 2 - $3 \mathrm{~m}$. Tinggi bak 1,2-1,5 $\mathrm{m}$, agar proses pembalikan dapat berlangsung dengan mudah. Ukuran bak ini dengan menggunakan asumsi proses pembalikan dilakukan dengan tenaga manusia dan tidak menggunakan mesin. Jumlah bak dekomposisi untuk 1 (satu) set proses minimal 3 (tiga) buah, yakni Bak I, Bak II dan Bak III. Ukuran (lebar) dari Bak I, boleh lebih lebar dari Bak II dan III. Misalnya Bak I, memiliki lebar $3 \mathrm{~m}$ dan lebar bak II dan III, $2 \mathrm{~m}$. Bangunan beratap diperlukan agar pukan tidak terkena hujan, sehingga tidak terlalu basah dan unsur haranya tidak tecuci oleh air hujan. Sedangkan bak-bak dekomposisi diperlukan agar proses dekomposisi dapat dikontrol serta terjadi efisiensi penggunaan/pemanfaatan ruang yang tersedia ${ }^{(7,22)}$. b. Pukan yang berasal dari pembersihan kandang atau yang dikeluarkan dari kandang, dimasukkan ke Bak I sampai penuh dan didiamkan di sana sampai 1 (satu) minggu. Setelah berumur 1 (satu) minggu, pukan di Bak I di pindahkan ke Bak II. Bak I yang kosong diisi kembali dengan pukan baru. Satu minggu berikutnya pukan di Bak II dipindahkan ke Bak III. Bak II yang kosong diisi kembali dengan pukan dari Bak I dan seterusnya. Terakhir, setelah pukan pada Bak III sdh 1 (satu) minggu lamanya, maka pukan tersebut dipindahkan ke tempat penampungan, sambil menunggu proses selanjutnya. Tata cara seperti tersebut, dikenal dengan pembalikan bergulir $^{(7,22)}$. Proses pembalikan di dalam bak dilakukan selama 3 (tiga) minggu, karena pada 2-3 minggu pertama merupakan proses dekomposisi yang aktif ${ }^{(6,7)}$,dan setelah proses tersebut diharapkan pukan sudah berubah menjadi pupuk organik (kompos) matang. Kalaupun belum, proses pematangan diharapkan terjadi pada saat proses penumpukan di tempat penampungan.

\section{KESIMPULAN}

Limbah kandang dari peternakan sapi potong, merupakan bahan baku yang sangat diandalkan pada pembuatan pupuk organik. Kandungan unsur hara makro utama, kadar $\mathrm{Fe}$, $\mathrm{pH}$, dan keberadaan mikroba fungsionalnya memenuhi Permentan 70 tahun 2011. Hal tersebut menunjukkan bahwa pupuk organik yang dibuat dari limbah kandang memiliki kualitas yang baik. Pada sisi lain, keberadaan mikroba kontaminan (E. coli dan Salmonella $s p$ ), positif pada pukan segar dan negatif pada pukan kering dan pupuk organik. Selain itu, analisa tingkat kematangan menyimpulkan bahwa pupuk organik yang diteliti belum mencirikan pupuk yang sudah stabil atau matang. Kedua hal tersebut merupakan permasalahan yang sering dihadapi pada pembuatan pupuk organik berbahan baku limbah kandang. Pemecahannya adalah memperpanjang waktu proses dekomposisinya melalui teknologi komposting sampai diperoleh pupuk yang memenuhi kriteria pupuk organik (kompos) matang, dan proses dekomposisinya berjalan secara aerobik sehingga menghasilkan suhu tinggi yang dapat membunuh mikroba patogen (kontaminan) dan bibit gulma.

\section{DAFTAR PUSTAKA}

1. Menteri Pertanian Republik Indonesia, (2010), Peraturan Menteri Pertanian No: 19/Permentan/OT.140/2/2010, tentang 
Pedoman Umum Program Swasembada Daging Sapi 2014.

2. Menteri Perdagangan Republik Indonesia, (2014), RI Butuh Impor Sapi 750 Ribu Ekor Pertahun.

Ekonomi.okezone.com/red/2014/05/21/320/ 988062.

3. Menteri Pertanian Republik Indonesia, (2011), Peraturan Menteri Pertanian No: 70/Permentan/SR.140/10/2011, tentang Pupuk Organik, Pupuk Hayati dan Pembenah Tanah.

4. Badan Pusat Statistik, (2014), Populasi Ternak Sapi Potong di Indonesia.

5. Haug, R.T., (1980), Compost Engineering, Principles and Practice, An Arbor Science Publisher Inc., Michigan.

6. Epstein, E., (1997), The Science of Composting, Technomic Publishing Company Inc., USA.

7. Wahyono, S., F.L. Sahwan dan F. Suryanto, (2016), Komposting Sampah Kota Skala Kawasan, Kupas Tuntas Dari AZ. BPPT Press.

8. Las, I., (2010), Arah dan Strategi Pengembangan Pupuk Majemuk NPK dan Pupuk Organik. Seminar Nasional Peranan Pupuk NPK dan Organik dalam Meningkatkan Produksi dan Swasembada Beras Berkelanjutan, Badan Penelitian dan Pengembangan Pertanian, Kementerian Pertanian, Jakarta.

9. Kementerian Pertanian Republik Indonesia, (2010), Pemulihan Kesuburan Tanah pada Lahan Sawah Berkelanjutan. Badan Litbang Pertanian dan Ditjen Tanaman Pangan, Jakarta.

10. Munawar, A., (2011), Kesuburan Tanah dan Nutrisi Tanaman, IPB Press, Bogor.

11. Iswandi, A., (2010), Peranan Pupuk Organik dan Pupuk Hayati dalam Peningkatan Produktivitas Beras Berkelanjutan. Makalah pada Seminar Nasional Peranan Pupuk NPK dan Organik dalam Meningkatkan Produksi dan Swasembada Beras Berkelanjutan. Balai Besar Litbang Sumberdaya Lahan Pertanian, Badan Penelitian dan Pengembangan Pertanian, Kementerian Pertanian, Jakarta.

12. Sahwan, F.L., S. Wahyono dan F. Suryanto, (2011), Evaluasi Proses Produksi Pupuk Organik Granul (POG) yang Diperkaya dengan Mikroba Fungsional.
Jurnal Teknologi Lingkungan, Pusat Teknologi Lingkungan-BPPT, 12 (1):7-16.

13. Sahwan, F.L., (2011), Analisis Potensi dan Produksi Pupuk Organik Granul (POG) Berbahan Baku Kotoran Hewan (Kohe). Jurnal Rekayasa Lingkungan, Pusat Teknologi Lingklungan-BPPT, 7 (2): 145152.

14. Soetjipto, N., (2010), Prospek Pasar Pupuk Organik Saat Ini dan Pasca Program Pupuk Organik Bersubsidi. Disampaikan pada Sosialisasi Permentan 28 Tahun 2009 di Pontianak, tanggal 10-11 Mei 2010.

15. Badan Standardisasi Nasional, (2004), Standar Nasional Indonesia, SNI 19-70302004 Tentang Spesifikasi Kompos dari Sampah Organik Domestik.

16. Lingga, P., (1991), Jenis dan Kandungan Hara pada Beberapa Kotoran Ternak. Pusat Pelatihan Pertanian dan Pedesaan Swadaya (P4S) Bogor.

17. Schuchardt, F., (1995), Parameter Analysis for Mature Compost. FAL Braunsweigh, Germany, (komunikasi pribadi).

18. Hogg, D., J. Bart, E. Favoino, M. Centemero, V. Caimi, F. Amlinger, W. Devliegher, W. Brinton and S. Antler, (2002), Review of Compost Standards in Belgium (Flanders). Nation Specific Supplement 2, The Waste and Resources Action Programme (WRAP).

19. Wahyono, S., F.L. Sahwan dan F. Schuchardt, (2003), Pembuatan Kompos dari Limbah Rumah Pemotongan Hewan. Pusat Pengkajian dan Penerapan Teknologi Lingkungan-BPPT.

20. Wahyono, S., F.L. Sahwan dan F. Suryanto, (2016), Teknologi Pengelolaan Limbah Rumah Pemotongan Hewan. BPPT Press.

21. Sahwan, F.L. dan S. Wahyono, (2011), Evaluasi Populasi Mikroba Fungsional pada Pupuk Organik Kompos (POK) Murni dan Pupuk Organik Granul (POG) yang Diperkaya dengan Pupuk Hayati. Jurnal Teknologi Lingkungan, Pusat Teknologi Lingkungan-BPPT, 12(2):187-196.

22. Sahwan, F.L., (2013), Teknologi Komposting Sampah Kota Skala Kawasan Metode Windrow Bergulir. Prosiding Workshop Diseminasi Teknologi Lingkungan, Tema: Diseminasi Pemanfaatan Iptek Guna Mendukung Pembangunan Yang Berwawasan Lingkungan, Kerjasama Bappeda- 
Pemerintah Daerah Pandeglang-Propinsi Banten dengan Pusat Teknologi Lingkungan, Kedeputian TPSA-BPPT. 